\title{
The Productive Response of Hens Exposed to Heat Stress
}

\author{
Monica PARVU*, Ioana C. ANDRONIE, Violeta E. SIMION, Adriana AMFIM
}

Spiru Haret University, Faculty of Veterinary Medicine, 9-11 Energeticienilor Bv., 3 Bucharest, Romania

*Corresponding author, email: monica_parvu@yahoo.com

Bulletin UASVM Animal Science and Biotechnologies 71(2) / 2014,

Print ISSN 1843-5262; Electronic ISSN 1843-536X

DOI:10.15835/buasvmcn-asb:10419

\begin{abstract}
The environmental stress has been implicated in adverse marked effects on egg production and eggshell quality of hens. The effect of heat stress was studied on three hen breeders (White Leghorn, Rhode Island, and White Plymouth Rock). The experiments were conducted on 4210 hens aged 31 weeks for each breed. The experimental period was 4 weeks. At age 32 weeks, the environmental temperature was $34.4-36.4^{\circ} \mathrm{C}$, into the hall. There were monitored the following productive parameters: feed intake, laying rate, egg weight, and shell thickness. After one week of heat stress the feed intake decreased with 32.4\% at White Leghorn females stock, $21.8 \%$ at Rhode Island and $27.3 \%$ at Plymouth Rock. After three weeks of heat exposure, the laying rate decreased with $10.4 \%$ at White Leghorn, $6.1 \%$ at Rhode Island, and 5.8\% at White Plymouth Rock $(\mathrm{p} \leq 0.05)$. The egg weight decreased with 3-3.2 g to all groups. The shell thickness was lower with $0.07 \mathrm{~mm}$ at White Leghorn, $0.04 \mathrm{~mm}$ at Rhode Island and $0.03 \mathrm{~mm}$ at White Plymouth Rock. The lower egg quality established a decrease of eggs for incubation. White Leghorn breed was more affected by the heat exposure, because the productive parameters production had a drastic decline. In this breed, mortality was determined by cannibalism and internal haemorrhages.
\end{abstract}

Keywords: heat stress, hens, parent stock

\section{INTRODUCTION}

The environmental stress has been implicated in adverse marked effects on egg production and eggshell quality of hens. Reports have conclusively indicated that poor performance (egg production and poor eggshell quality) of layers reared in thermally-stressed environments could be adduced to a complex interplay of low feed intake, malfunctioning of the endocrine system, acid-base imbalance and poor physiological functioning of organs and mechanisms connected with the entire egg production process, via follicular recruitment and growth, ovulation, egg formation, shell formation, egg development, oviposition and oviposition interval (Oguntunji and Alabi, 2019). The action of environmental factors is different varying with the breeds or hybrids. At Albo hybrid, the egg production decreased by 9.2\%, comparative with Roso hybrid production (Andronie et al., 2009).

Starting from these considerations, our investigation monitored the influence of heat on the productive capacity of three hen breeders (White Leghorn, Rhode Island and White Plymouth Rock) widely used in Romania to obtain the commercial hybrids used for egg and meat production.

\section{MATERIALS AND METHODS}

The experiments were conducted on three groups (White Leghorn, Rhode Island and White Plymouth Rock). Each group has 4210 hens aged 31 weeks (peak egg production). The experimental period was 4 weeks. The hens were breeding on the floor. Starting at age 32 weeks, the environmental temperature was $34.4-36.4^{\circ} \mathrm{C}$, into the hall.

The diets used in our trials were isocaloric and isoprotein, providing the requirement of nutrients according to the feeding norms. The lighting programs were specifically for each breed. The monitored parameters were feed intake, laying rate, egg weight, and shell thickness. The feed intake was recorded daily. The laying rate was determined weekly, based on the daily egg 
production. The egg weight and egg shell thickness were measured weekly.

The performance data were processed statistically by ANOVA.

\section{RESULTS AND DISCUSSION}

The data concerning the feed intake are presented in Table 1. Comparing with the results at 31 weeks, after one week of heat stress the feed intake decreased with $32.4 \%$ at White Leghorn females stock, $21.8 \%$ at Rhode Island, and $27.3 \%$ at White Plymouth Rock (Fig. 1). It was observed that the heat temperature had influenced the feed intake; the differences were significant $(p \leq 0.05)$. The different results between the breeds were explained because of the genetic particularities.

In the literature, it was mentioned that at Albo hybrid exposed at $35^{\circ} \mathrm{C}$ the feed decreased with $21.2 \%$. At Roso hybrid exposed in same conditions, the feed intake was lower with 15.5\% (Andronie et al., 2009). The response of the layers to overheating due to high environmental temperatures is the

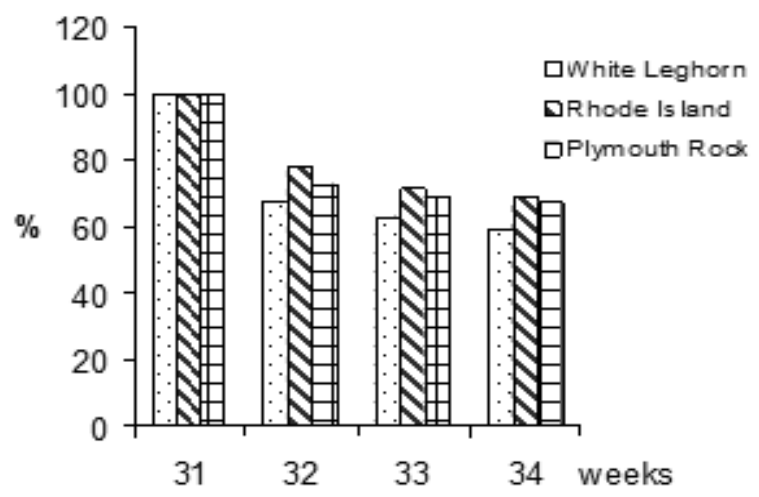

Fig.1. Feed intake

depression of the nutrient intake. After 7 days of exposition to $31^{\circ} \mathrm{C}$, the feed intake of Hy-Line
Brown laying hens decreased with $47.6 \%$ (Song et al., 2012).

In Table 2 it shows the experimental results concerning the laying rate. It was observed that the laying rate decreased (in 3 weeks of heat) with $10.4 \%$ at White Leghorn, $6.1 \%$ at Rhode Island and $5.8 \%$ at White Plymouth Rock (Fig. 2). The differences were significant $(\mathrm{p} \leq 0.05)$.

Those results are in agreement with the data presented in literature [4], that both laying rate and egg quality are decreased by the heat.

The literature shows that the laying rate decreased with $6.5 \%$ after 7 days of heat exposure (Song et al., 2012). As temperatures rise above $32-35^{\circ} \mathrm{C}$, egg production levels may also decline; as total nutrient intake is insufficient to support normal rates of lay (Bird etal., 1988).

In our experiment, it was observed that the decrease of laying rate was more drastic in the first week of heat stress, with $4.4 \%$ at Leghorn hens, $3.2 \%$ at Rhode Island hens and in the third week of heat, the decrease was less drastic, because the organism of birds adapted (in some limits) to the high temperature. The egg weight decreased with 3-3.2 g to all groups. As feed intake declines, the first production trait to respond is egg weight, increasing the percent of medium and small eggs (Bird et al. 1988). The literature noticed that only $40-50 \%$ of the adverse effects of the heat (i.e. lower egg weight and lower laying percentage) can be attributed to the lower feed intake, the balance being on the account of the hen's capacity to acclimatize (Nyoya, 1995).

The shell thickness was influenced by the heat exposure, too (Tab. 3). It was observed that the shell thickness decreased significantly during those three breeds. Also, the percentage of eggs with haemorrhage and eggs without shell

Tab. 1. Feed intake (g/day)

\begin{tabular}{cccc}
\hline Age (weeks) & White Leghorn & Rhode Island & Plymouth Rock \\
\hline 31 & $108.05 \pm 6.73$ & $119.38 \pm 5.91$ & $172.58 \pm 8.26$ \\
32 & $73.33 \pm 3.26 \mathrm{a}$ & $93.67 \pm 5.42 \mathrm{a}$ & $125.43 \pm 6.22 \mathrm{a}$ \\
33 & $68.15 \pm 4.77 \mathrm{a}$ & $85.73 \pm 6.34 \mathrm{a}$ & $119.97 \pm 7.35 \mathrm{a}$ \\
34 & $64.52 \pm 5.08 \mathrm{a}$ & $82.26 \pm 4.96 \mathrm{a}$ & $116.24 \pm 5.86 \mathrm{a}$ \\
\hline
\end{tabular}

Tab. 2. Laying rate (\%)

\begin{tabular}{cccc}
\hline Age (weeks) & White Leghorn & Rhode Island & Plymouth Rock \\
\hline \hline 31 & $91.6 \pm 3.2$ & $93.3 \pm 2.6$ & $87.1 \pm 1.3$ \\
32 & $87.2 \pm 1.7$ & $90.1 \pm 1.8$ & $84.2 \pm 1.7$ \\
33 & $83.7 \pm 2.1$ & $88.4 \pm 2.2$ & $82.0 \pm 2.1$ \\
34 & $81.2 \pm 1.3 \mathrm{a}$ & $87.6 \pm 1.9 \mathrm{a}$ & $81.3 \pm 1.8 \mathrm{a}$ \\
\hline
\end{tabular}




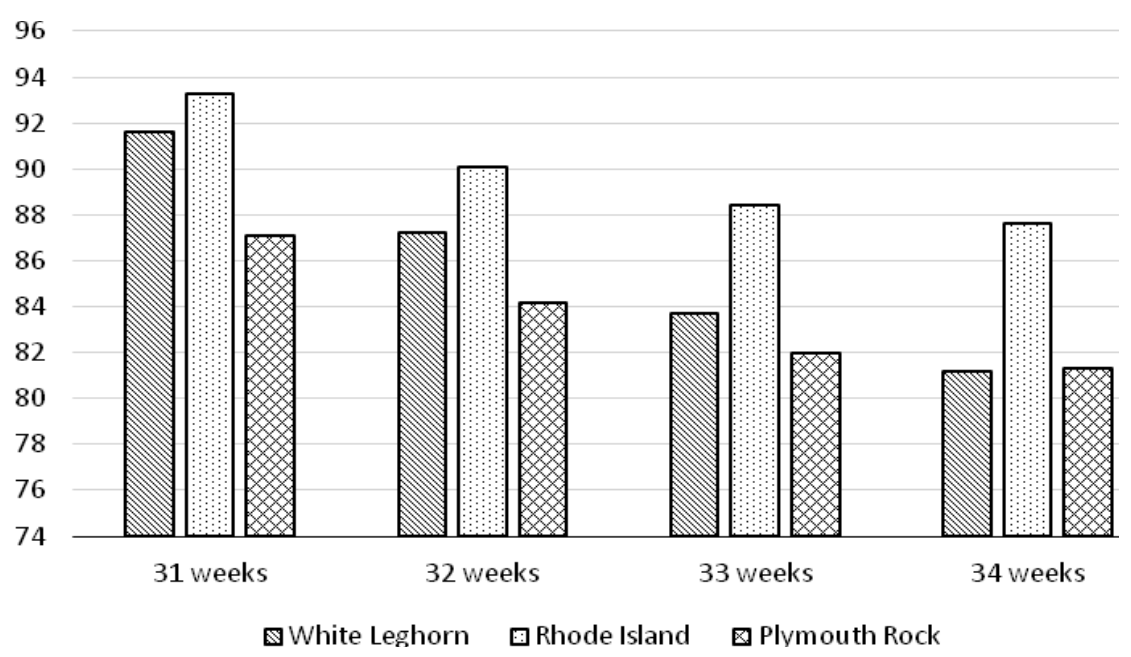

Fig.2. Laying rate (\%)

Tab. 3. Eggshell thickness

\begin{tabular}{cccc}
\hline Shell thickness $(\mathrm{mm})$ & White Leghorn & Rhode Island & Plymouth Rock \\
Before heat stress & $0.31 \pm 0.022$ & $0.37 \pm 0.016$ & $0.36 \pm 0.014$ \\
Heat stress & $0.24 \pm 0.012$ & $0.32 \pm 0.019$ & $0.33 \pm 0.117$ \\
\hline
\end{tabular}

were bigger at heat exposure. The results can be explained by the haemorrhages in the oviduct and by the perturbation of calcium metabolism.

The literature shows that the most frequent result of heat stress is a decrease in egg shell quality (Bird et al., 1988). The high percentage of shell-less eggs produced by hens under heat stress is explained by the fact that the high temperatures and higher breathing intensity, the partial pressure of $\mathrm{CO}_{2}$ and of the blood bicarbonates ( $\mathrm{HCO}_{3}$ ions) decrease. In consequence, without the supply of these ions, the shell of eggs becomes thin and frail (Yahav, 1998).

Particularly at White Leghorn hens, it was observed the apparition of cannibalism, like effect of the heat stress. In this cause, the mortality increased with $10.3 \%$, the differences being significant $(p \leq 0.05)$.

\section{CONCLUSION}

White Leghorn breed was more affected by the heat exposure, because the zootechical production had a drastic decline.

The egg quality was affected equally by the heat exposure on all breeds.

The heat stress established the appearance mortality by cannibalism internal haemorrhages on white leghorn hens.
The lower egg quality (egg weight, shell thickness and egg without shell) established a decrease of the eggs for incubation.

\section{REFERENCES}

1. Andronie Ioana Cristina, Monica Parvu, V Andronie (2009). Productive capacity of the hybrid Albo 70 and Roso SL layers exposed to heat stress, Proceedings of the 14th International Congress of the International Society for Animal Hygiene, Vechta, Germany 19-23 July.

2. Bird N, P Hunton, WD Morrison, LJ Weber (1988). Poultry: Heat Stress in Caged Layers, Factsheet 8: 88-95.

3. Larbier M, B Leclercq (1994). Poultry Nutrition and Alimentation (Nutriţia şi alimentaţia păsărilor), Ed AJutus - D, București, 26-30.

4. Nyoya J (1995). Effect of diet and natural variations in climates on the performance of laying hens, British Poultry Sci., 36: 537-554.

5. Oguntunji AO and OM Alabi (2010). Influence of high environmental temperature on egg production and shell quality: a review, World's Poultry Science Journal, 66: 739-750.

6. Song Zhigang, Lei Liu, Ardashir Sheikhahmadi, Hongchao Jiao and Hai Lin (2012). Effect of Heat Exposure on Gene Expression of Feed Intake Regulatory Peptides in Laying Hens, Journal of Biomedicine and Biotechnology Volume 2012, Article ID 484869, 8 pages doi:10.1155/2012/484869

7. Yahav S (1998). Physiological responses of chickens and turkey to hot climate, $10^{\text {th }}$ European Poultry Conference Jerusalem Israel June 21-26. 